\title{
CORRUPTION: A PROBLEM IN ROMANIAN PUBLIC PROCUREMENT
}

\author{
Ionel Preda \\ The Bucharest University of Economic Studies, Bucharest, Romania \\ predaionel4@gmail.com
}

\begin{abstract}
Even though the relevance of corruption is very high in all fields of activity, the specialized literature in the field of public procurement has paid very little or even no attention to this crucial phenomenon. The field of public procurement presents a high risk of corruption, the evidence being the large number of high-level corruption cases in several Member States of the European Union. The study presents the specialized literature related to corruption in public procurement in the European Union and United States of America, analyzes the level of corruption in public procurement in Romania, the causes that generate corruption and the main measures to combat it. The article also presents the results of a survey realized among the purchasers from Romania which addresses the main elements of corruption in the field of public procurement. The survey analyzes issues related to corruption in public procurement in Romania, such as: level of corruption, control over corruption, frequency of occurrence of corruption acts, procurement procedures most prone to corruption, characteristics of the procurement procedures that favors the occurrence of corruption, most widespread way of manifesting corruption, most important consequence of corruption, percentage of increasing contract costs due to corruption, most effective anti-corruption measure.
\end{abstract}

Keywords: public procurement, corruption, bribery, fraud, conflict of interest.

\section{INTRODUCTION}

At present, the phenomenon of corruption is one of the most important topics of discussion at any level and in any field, representing an important challenge of the contemporary world, both in the poor, developing and developed states (Păceșilă, 2004).

Corruption is one of the most important issues of public policy implementation. Also, corruption is a major impediment to developing countries with emerging economies and in improving the quality of life in countries with developed economies (Loosemore \& Lim, 2015; Tabish \& Jha, 2011; Treisman, 2007). The major political challenges at European level can be solved by carrying out efficient public procurement. These challenges are: fight against corruption, job creation, sustainable economic growth (social and environmental), modernization of central and local public administrations, improving fiscal discipline, facilitating the participation in the procurement procedures of small and medium-sized 
Preda, I.

enterprises, innovation and increasing citizens' level of confidence in public authorities (European Commission, 2017).

At European level, Romania belongs to the category of countries which present a high degree of corruption and risks in the field of public procurement. This category includes countries such as Czech Republic, France and Italy. In European Union, countries with a low degree of corruption and low risks in the field of public procurement are Germany, Sweden and Denmark (CJI - The Clean Justice Initiative, 2015).

\section{LITERATURE REVIEW}

The most frequently used definitions for corruption are "the use of public function for private gains" (Gray \& Kaufmann, 1998) or "the abuse of power in order to obtain private gains" (EC - European Council, 2014).

TI - Transparency International (2015) categorizes corruption into two major categories: "petty corruption", which refers to violations of the law by civil servants at medium and small level and "grand corruption", which refers to acts of corruption committed by relevant institutions such as governments and courts. A subcategory is represented by "political corruption", which refers to manipulations of policies, regulations and institutions by political decision makers (TI - Transparency International, 2015). Depending on the frequency of occurrence of the phenomenon, corruption is classified as: "sporadic corruption", related to occasional opportunities and "systemic corruption", which is an integrated and essential aspect of social, political and economic systems (The Anti-Corruption Resource Centre, 2015). In the case of infrastructure projects, The Global Infrastructure Anti-Corruption Centre (GIACC, 2008) identified and described 47 possible acts of corruption, which are divided into three phases: prequalification and bidding, project execution and dispute resolution.

The fraud consists of three main elements: opportunity, justification (need for explanation of acts of corruption) and financial pressure (in form of incentive or motivation). These three elements form the socalled "triangle of fraud". Breaking this triangle can be done only by the action on the opportunity element, by implementing effective control and prevention mechanisms (Cendrowski et al., 2007).

According to Buchner, S. et al. (2008), bribery is a phenomenon difficult to prove and study, due to its illegal nature, which is a contributory factor for hiding it.

It is estimated that because of systematic corruption, the costs of governmental procurement may be increased by $20-25 \%$, in some cases even up to $50 \%$ and the quality of the products, services and works is lower than that specified in procurement procedures (Evenett \& Hoekman, 2005; TIR Transparency International Romania, 2014). 
The reason for the appearance of these additional costs lies in the fact that companies which bribe recover these amounts by increasing the value of the contracts which are paid from public funds.

In order to emphasize the importance of this issue and the size of the funds involved, we mention that Kaufman (2004) estimated the costs of corruption in the USA in 2004 at about 200 billion dollars per year and the OECD Initiative for the Development of the Procurement Systems Capacity estimated in 2005 the worldwide losses due to corruption in public procurement at over 3 trillion dollars (TIR, 2014). According to The Anti-Corruption Resource Centre (2015) and GIACC (2008), corruption can manifest itself in several ways, the most widely known being: bribery (money and other benefits), extortion (offenses that obtain money or other values through abuse of authority), fraud, (deception in order to obtain a financial or non-financial advantage), embezzlement (the misappropriation of property or funds by a public official), conflict of interests (the participation of a civil servant in activities that endanger his independence, objectivity and professional judgment) and nepotism (granting favors to relatives by decision makers).

The consequences of corruption in public procurement in Romania are: cost increase (financial impact), loss of quality and investors (economic impact),- the impact on the safety and health of people, the impact on the development of research and innovation, environmental impact, affectation of economic development, affectation of competition in the market, decrease of confidence in public institutions and the Government and erosion of values (TIR, 2014).

The corruption perceptions index (CPI) measures the perceived levels of corruption in the public sector in 180 countries (Transparency International, 2014). CPI is used to measure the transparency, fairness and integrity of public sector activities / processes / procedures.

$\mathrm{CPI}$ is a quantitative indicator of corruption in various countries and is used for the evaluation of civil servants and politicians regarding the degree of acceptance of bribes, illicit payments, misappropriation of public funds and similar crimes (Rahman et al., 2015).

In the case of Romania, this index has the value of 47 on a scale from 0 (very high level of corruption) to 100 (very low level of corruption), Romania being placed at position 61 out of 180 countries analyzed (Transparency International, 2018). The evolution of the corruption perception index for Romania between 2009 and 2018 is shown in Figure 1. 
Preda, I.

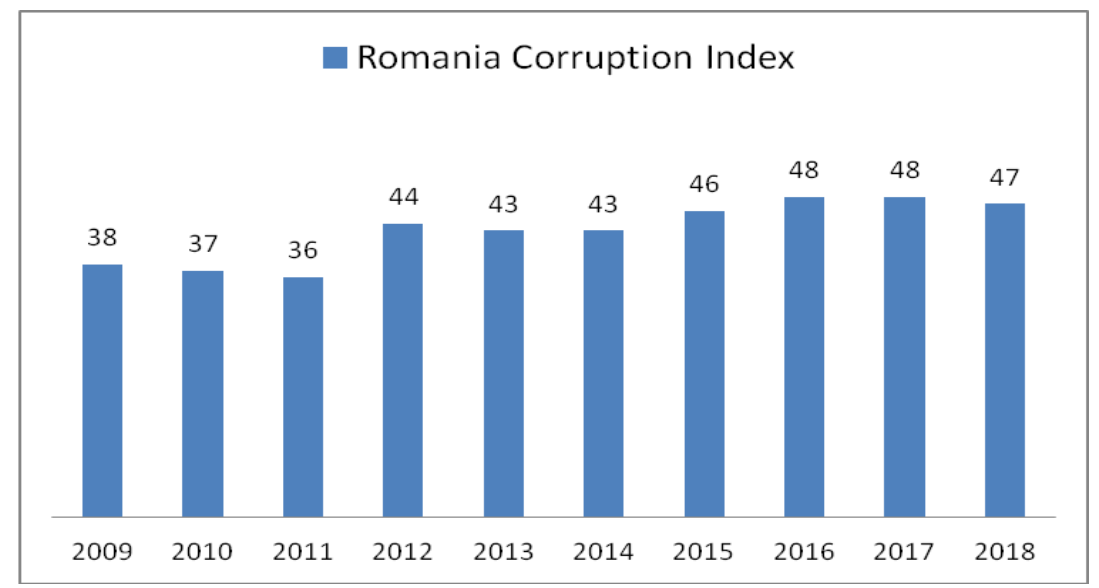

FIGURE 1: THE EVOLUTION OF THE CORRUPTION PERCEPTION INDEX FOR ROMANIA BETWEEN 2009 AND 2018

Source: Trading Economics (2019)

Egger \& Winner (2005) analyzed the role of corruption as a "helping hand" in attracting foreign direct investments. The research of the two authors has identified both a series of negative effects of corruption such as: waste of resources, bribery and higher risks, as well as a number of positive effects such as: accelerating bureaucratic processes and increasing the possibility of accessing publicly funded projects.

The vast majority of authors disagreed with the positive effects of corruption. Shleifer \& Vishny (1993) have highlighted the hidden aspect of corruption, which makes this phenomenon difficult to identify and manage. Corrupt civil servants can intentionally delay granting the approvals they should normally grant, hoping they will receive bribes, and companies will lose valuable time trying to meet the requirements imposed by these officials (Kaufmann \& Wei, 1999). Wedeman (1997) has shown that if corruption is a well-organized phenomenon, then it affects the country's economy very much.

Mo (2001) estimated that a 1\% increase in the level of corruption reduces the economic growth rate by $0.72 \%$. Because the money paid through corruption reduces the profit of the companies, then the companies could try to recover some of the profit by subcontracting at a lower cost, with negative effects on quality and on the quality / price ratio (value for money) (May et al., 2001).

Tanzi \& Davoodi (1998) analyzed the qualitative effects of corruption, as follows: increases income inequalities, reduces revenues and increases public spending, thus contributing to the increase of the fiscal deficit, acts as an arbitrary tax, distorts incentives, increases the number of controls and inspections, reduces the role of government / government agencies in the awarding and execution of contracts, reduces the legitimacy of democracy and the market economy and acts as a barrier to the entry of small and medium-sized companies into the market (Tanzi \& Davoodi, 1998). 
Gillanders (2014) demonstrated that regions with a higher level of corruption than the national average have a poorer infrastructure than others. This situation is due to the fact that, in the case of infrastructure projects, corruption has at least two important effects: it distorts the market and worsens the cost / benefit ratio (Locatelli et al, 2016).

\section{THE MAIN CAUSES THAT GENERATE CORRUPTION IN PUBLIC PROCUREMENT IN ROMANIA}

Păceșilă (2004) identified a number of causes of the corruption phenomenon in the Romanian public administration: inconsistent and uncorrelated legislation with managerial measures to fight corruption, working conditions and especially the feeling of job insecurity, lack of communication and transparency in the public sector, existence of a degree of politicization of the public administration, lack of moral and material incentives and lack of an active civil society (a passive attitude of citizens, lack of reporting of corruption causes).

At EU level, the first report analyzing corruption in public procurement was launched in 2014. The report also contains the conclusions of a survey carried out between February 2013 and March 2013. In the case of Romania, the results of this survey were as follows: $64 \%$ of the respondents considered that the economic environment was characterized by nepotism and clientelism, $91 \%$ appreciated that the level of corruption is high, with an EU average of $75 \%, 42 \%$ considered that family and friends were favored in various public institutions, $82 \%$ appreciated that bribery and the use of connections was an easy way to obtain public services, $38 \%$ considered that the financing of political parties was done in exchange for public procurement contracts (European Commission, 2014).

Zarkada-Fraser \& Skitmore (2000) concluded that the stakeholders more susceptible to corruption are young, less loyal to the organizations they belong to, not affiliated with professional bodies and with a low level of satisfaction.

Excessive bureaucracy and inability to purchase intelligently result in higher administrative costs that affect the delivery terms, quality and price of the products. Other additional effects are the purchase of products containing obsolete innovations, underperformance and missed opportunities of reducing life cycle costs (Coggburn, 2003).

Søreide (2002) considers that public procurement is critical because corruption can occur through: invitation to the procurement procedure (the contracting authorities may have the power to decide which economic operators will be invited to participate in the procedure), bidders qualification (limiting the number of bidders using the requirement of previous professional experience), choosing a certain technical solution that limits the number of bidders, transmission of confidential information about the offer of an economic operator and avoiding competitive procurement procedures due to emergency. 
Preda, I.

Other methods used to damage a procurement procedure are: restrictive criteria of qualification and selection, transmission of information about the offers of the competitors or arrangements regarding the reception of the services or works (TIR, 2014).

According to Lefter (2015), during a procurement procedure corruption manifests itself on certain risk areas such as: development of technical specifications that match the products marketed by certain tenderers, unjustified exclusion from the award procedure of a tenderer, existence of conflicts of interest, unjustified use of the negotiation procedure on grounds of urgency and absence of an analysis of the unusually low prices received by the contracting authority.

Another factor that favors corruption in public procurement in Romania is the fact that about $40 \%$ of the procurement contracts are awarded by direct acquisitions, which means without a competitive procedure. In this category are included the procurement with estimated value lower than 135,060 lei, without VAT for products and services and 450,200 lei, without VAT for works, contracting authorities being able to purchase the desired product / service from a single firm, on the basis of a single tender, by sending an invitation to the tenderer through the Romanian Electronic Public Procurement System (SEAP), without comparing it with other offers.

\section{MEASURES TO COMBAT CORRUPTION IN PUBLIC PROCUREMENT}

Akbar \& Vujić (2014) and Auti \& Skitmore (2008) consider that the phenomenon of corruption can be greatly reduced by increasing the level of education and by making cultural changes that lead to a government capable of producing and implementing policies that address this phenomenon. Unfortunately, cultural changes are very slow processes that can last for decades.

Corruption can be reduced by increasing the likelihood of detection and punishment, increasing penalties provided by the law for acts of corruption and increasing the benefits for honest civil servants. These measures require reforms and increased transparency (Rose-Ackerman, 1996).

Tabish \& Jha (2012) showed that there is a inverse correlation between indicators regarding corruption and transparency, professional standards, fairness of penalties, compliance with contractual clauses and procedures. Also, Kenny (2012) showed that the transparency of public procurement procedures is a key factor in the fight against corruption. 


\section{RESEARCH METHODOLOGY}

This research constitutes a survey drawn up on the analysis carried out on a questionnaire basis (the methodological approach is a qualitative analysis). Research is an empirical study obtained by mathematical processing of experimental data.

The advantages of the surveys that use the questionnaire are: easy application and interpretation, quick completion and the fact that it requires limited resources for transmitting questions and interpreting the results. Standardized answers do not require the creativity of the respondents and based on them interpretation of results is made much easier compared to other methods such as the interview because answers are already written.

The main limitation of the questionnaires is that they do not require the creativity and involvement of the respondent in achieving / obtaining complex answers that express their own point of view, because questionnaires have predetermined answer variants (multiple or unique).

The research methodology consists of studying the specialized literature, developing the questionnaire, identifying the target group, sending the questionnaire (online application), receiving responses, analyzing and interpreting the answers.

\section{PRESENTATION OF THE TARGET GROUP}

The target group consisted of 61 persons ( 32 purchasers and heads of public procurement departments from the contracting authorities and 29 purchases from the economic operators).

The questionnaire was sent by electronic mail, and the completion period was 15.10.2019 - 13.11.2019. The questionnaire consisted of 15 questions, and their answers were based on multi-variant grids, single-response grids and grading scales.

Of the sample of 61 respondents, 27 were men ( $44.26 \%$ weight) and 34 women ( $55.74 \%$ weight).

Most of the surveyed purchasers belonged to the age group 40-50 years (30 respondents, $49.18 \%$ weight) and to the age group 30-40 years (23 respondents, $37.70 \%$ weight). The age group 20-30 years had a weight of $8.20 \%$ and the age group over 50 had the lowest weight of only $4.92 \%$.

As regards the level of training in the field of public procurement, 49 of the surveyed purchasers (80.33\% weight) have graduated from the Romanian National Qualifications Authority (ANC) and obtained the qualification of "Public Procurement Expert" and 7 respondents (11.48\% weight) have graduated postgraduate studies in the field of public procurement. No respondents have completed master studies in the field of public procurement and 5 respondents ( $8.19 \%$ weight) have no training in 
Preda, I.

this area. The questioned purchasers are very well trained in the field of public procurement, the vast majority having the qualification of "public procurement expert".

Regarding the experience of respondents in the field of public procurement, 11 of the surveyed purchasers (18.03\% weight) had an experience in the field of public procurement between 0 and 5 years, 20 respondents (32.79\% weight) between 5 and 10 years, 20 respondents (32.79\% weight) between 10 and 15 years, 7 respondents (11.48\% weight) between 15 and 20 years and only 3 respondents ( $4.92 \%$ weight) had more than 20 years of experience.

\section{FINDINGS, DATA ANALYSIS AND INTERPRETATION}

The level of corruption in the field of public procurement needs to be analyzed, because, depending on this level, the necessary measures must be taken to combat this phenomenon.

To find out how high the level of corruption is, respondents were asked the question: "Is the level of corruption in public procurement in Romania high?"

$67.21 \%$ of the respondents ( 41 persons) replied that the level of corruption was high and $32.79 \%$ ( 20 persons) replied that they don't know. It should be noted that no purchaser considers that the level of corruption was low. Even though the great majority of the purchasers considered that the level of corruption was high, it is very likely that some of the respondents who answered with "I don't know" have given this answer for fear of self-incrimination.

Moreover, to all questions regarding corruption, it is difficult to get answers that fully correspond to reality due to the hidden and illegal nature of this phenomenon.

This research confirms that the level of corruption in Romania in the field of procurement remains high, thereby confirming the conclusion of the European Commission (2014) which established that in 2013 the overall level of corruption in Romania was high.

Control over corruption in public procurement is also a topic of great interest. Purchasers' perception of control over corruption was addressed by the question: "Is there a control over corruption in the field of public procurement in Romania?"

To this question, $63.93 \%$ of the surveyed purchasers (39 respondents) replied that there was no control over corruption, and $27.87 \%$ answered that they don't know. Unfortunately, as expected, only $8.20 \%$ of the respondents answered that there was a control over corruption.

The vast majority of negative responses show that corruption is currently a major problem in the area of public procurement, which must be treated as a priority. 
Unfortunately, these results show that in the case of public procurement in Romania the so-called "triangle of fraud" conceived by Cendrowski et al. (2007) has not yet been broken by implementing efficient prevention and control measures.

An important element of corruption is the frequency of occurrence of corruption acts. Depending on the frequency of occurrence, corruption in the field of public procurement can be sporadic or systemic.

The following question asked respondents about the frequency of occurrence of corruption in the field of public procurement: "Depending on the frequency of occurrence, corruption in public procurement is". Response options are: sporadic (occasional opportunities) or systemic.

$47.54 \%$ of the surveyed purchasers (29 respondents) replied that the frequency was sporadic while, surprisingly, $52.46 \%$ of the respondents (32 purchasers) believed that the frequency of corruption was systemic (Figure 2).

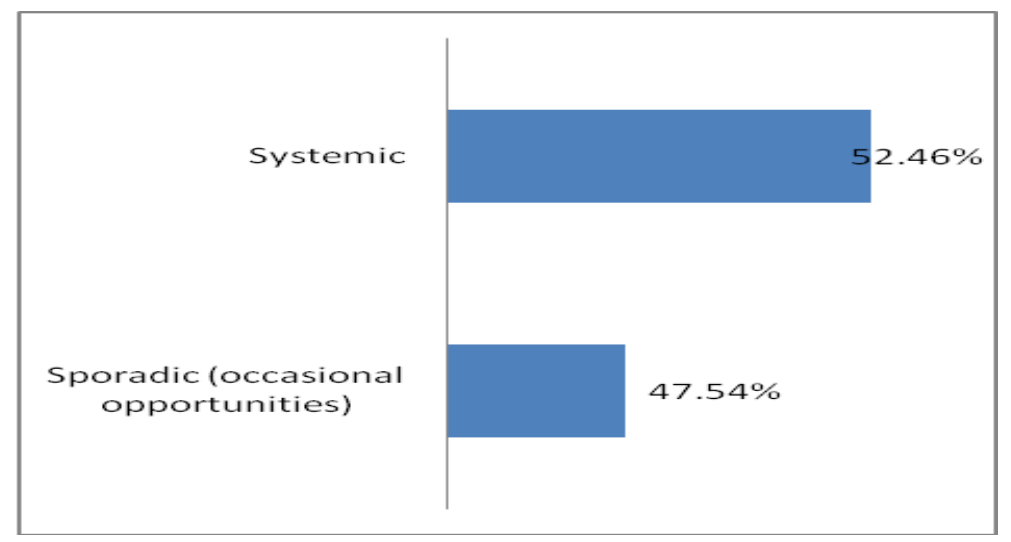

FIGURE 2. THE FREQUENCY OF OCCURRENCE OF CORRUPTION ACTS

Source: own processing

Corruption is favored more or less depending on some characteristics of procurement procedures, such as: estimated value of the procedure (large or small), type of procedure (competitive or restricted), qualification and selection conditions (more restrictive or less restrictive) or the number of offers received (large or small).

The following question addresses this matter: "Which feature of the procurement procedures favors the occurrence of corruption?"

$51 \%$ of the surveyed purchasers considered that the restrictive qualification and selection conditions were the characteristics that favor corruption the most (Figure 3). The restrictive qualification and selection conditions favor the occurrence of corruption the most because the contracting authority can impose technical specifications, qualification conditions such as similar experience, holding certain 
Preda, I.

authorization / certifications (quality, environment, health) leading to artificial restriction of competition in order to favor a certain economic operator.

These results confirm the findings of the study conducted by TIR (2014) which established that one of the main methods used for the vitiating of procurement procedures is the imposition by contracting authorities of restrictive selection and qualification criteria which artificially restrict competition.

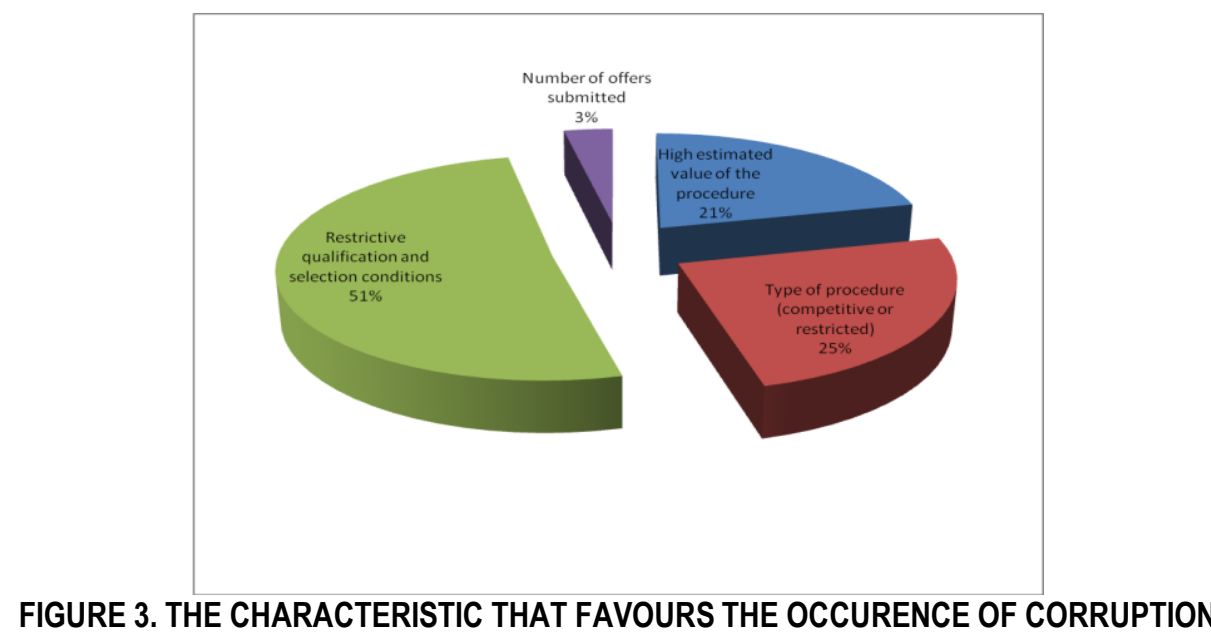

Source: own processing

It follows the type of procedure (restricted or competitive) with a weight of $25 \%$ and the high estimated value of the procedure with a weight of $21 \%$. The estimated value of a procedure favors the occurrence of corruption because if the estimated value is higher, then the potential profit that can be obtained by the offeror increases. Thus, the offeror is more tempted to tip the balance of the evaluation process in his favor by using illegal means. According to the respondents, the number of offers submitted is the characteristic least prone to corruption, with a weight of only $3 \%$.

Currently, the field of public procurement in Romania is regulated by four laws: Law no.98/2016 (public procurement), Law no. 99/2016 (sectoral procurement), Law no. 100/2016 (works concessions and service concessions) and the Romanian Government Emergency Ordinance no. 114/2011 (security and defense procurement).

Respondents' opinions regarding the vulnerability of each type of legislation were obtained by asking the question: "What type of legislation is more vulnerable to corruption?"

$44 \%$ of the surveyed purchasers considered that the most vulnerable laws were Law no. 98/2016 (public procurement) and Law no 100/2016 (works / services concessions), and 10\% consider that the most vulnerable was Law no 99/2016 (sectoral procurement) (Figure 4). According to the respondents, 
Preda, I.

CORRUPTION: A PROBLEM IN ROMANIAN PUBLIC PROCUREMENT

the least vulnerable legislation was GEO no 114/2011 (defense / security procurement) with a share of only $2 \%$.

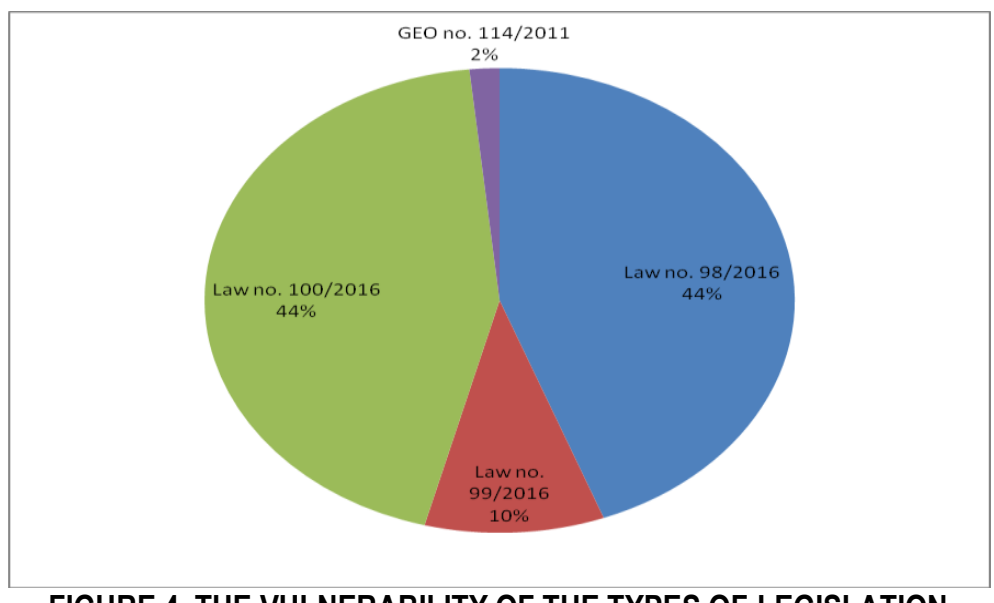

FIGURE 4. THE VULNERABILITY OF THE TYPES OF LEGISLATION

Source: own processing

It should be noted that the vast majority of budgetary funds are spent by Law no 98/2016 (public procurement). A limitation of the answers received is that there are not many purchasers who carry out procurement on all four types of legislation, because contracting authorities usually carry out procurement procedures on one, maximum two types of legislation (meaning that the authorities are quite "specialized").

As the types of procurement procedures present different risks to corruption, it is important to identify which procedures are most prone to corruption. Thus, the respondents were asked the question: "What type of procurement procedure is most prone to corruption?"

The highest share of the answers received (43\%) is presented by the negotiation procedure without the publication of a tender notice, a non-competitive procedure which is carried out through successive negotiations with a single tenderer, for reasons of urgency, technical reasons or the protection of an intellectual property right (Figure 5). In the opinion of the respondents, the following procedures more prone to corruption were direct procurement ( $31 \%$ weight) and own procedure ( $20 \%$ weight). 
Preda, I.

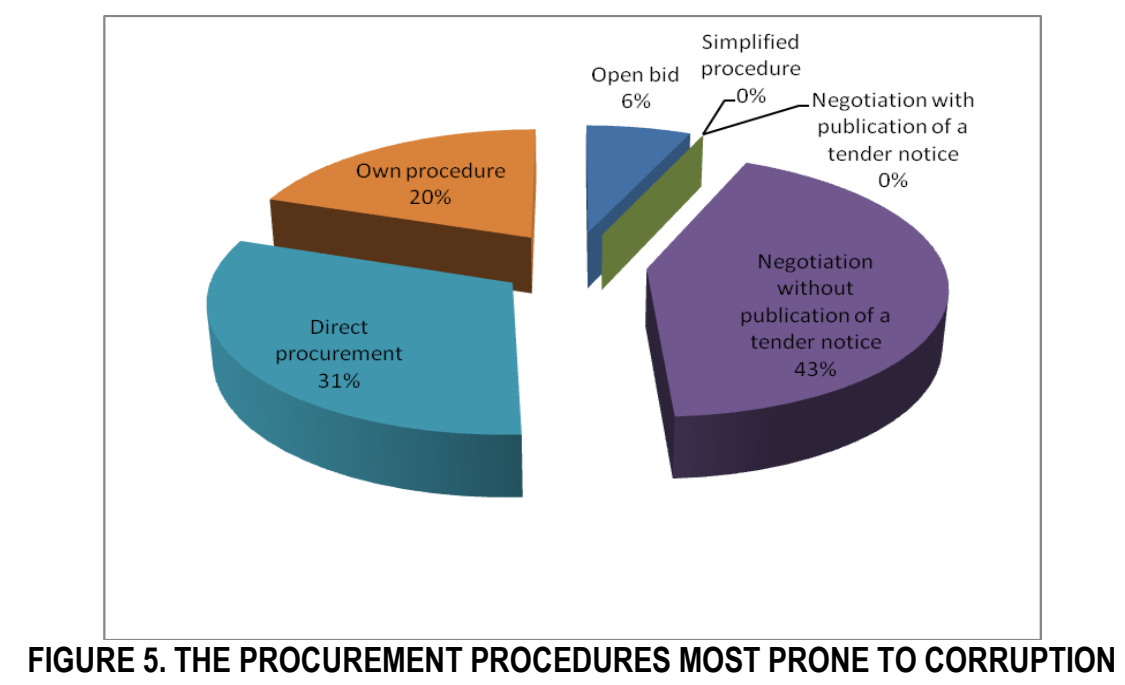

Source: own processing

The own procedure is a competitive procedure that is organized by exception from the provisions of Law no. 98/2016 regarding public procurement, for reasons related to maintaining the confidentiality of the data that offerors have access to during the procedure (data which may be classified and cannot be made public). This means that the contracting authority addresses to several offerors, but send the tender documents and invites to submit only the offerors who have committed themselves to the confidentiality of the data they will have access to. The risk of corruption appears in the situation where the contracting authority invites to the procedure only certain offerors (chosen on other less objective criteria).

The direct procurement is not a procurement procedure as defined by Romanian law. Each contracting authority can directly purchase services / products whose estimated values are below the value threshold of 135,060 lei, excluding VAT. Therefore, the contracting authority addresses directly a single offeror, from which it buys the necessary products and services. The specificity of direct procurement is that they are non-competitive, in very large numbers and small amounts. The risk of corruption occurs when a contracting authority carries out a large number of direct procurements from the same offeror, regardless of the type of product / service purchased. It should be noted that at present, in Romania about $40 \%$ of the funds for public procurement are spent through direct procurements.

As expected, the open bid (competitive and transparent procedure with estimated values higher than 648,288 lei, excluding VAT for services / products) obtained a weight of only $6 \%$. The respondents considered that the simplified procedure (similar to the open bid, with estimated values lower than 648,288 lei, excluding VAT for services / products, and with shorter time limits) and the negotiation with prior publication of a tender notice are the types of procedures less prone to corruption. 
An indicator of corruption is the method of vitiating public procurement procedures: bribery, conflict of interest, nepotism, embezzlement, abuse of power, fraud or blackmail.

The following question addresses the identification of the most widespread way of manifesting corruption, as follows: "Which way of manifesting corruption is the most widespread in the field of public procurement?"

$77.42 \%$ of the surveyed purchasers considered that the most widespread form of corruption was bribery, $16.13 \%$ of respondents considered the conflict of interest, and $6.45 \%$ considered the abuse of power (Figure 6).

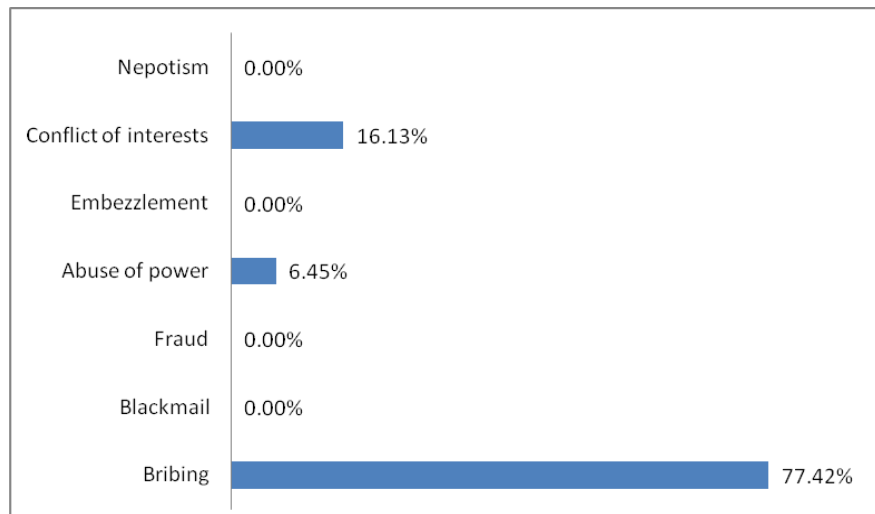

FIGURE 6. THE MOST WIDESPREAD WAY OF MANIFESTING CORRUPTION

Source: own processing

Thereby, these results also confirm in the area of public procurement in Romania the findings of the anti-corruption Resource Center (2015) and the GIACC (2008) studies that bribery is the most widespread form of corruption.

Conflict of interest occurs when decision-makers within the contracting authorities carrying out the procurement procedure and the persons within the management bodies of offerors are relatives up to and including the second grade.

The most important consequences of corruption acts in the field of public procurement are: higher prices, delays in product delivery, lower quality products, higher maintenance / exploitation costs, etc. The following question analyzes the most important consequences of the phenomenon of corruption: "What is the most important consequence of corruption in procurement procedures?" $61 \%$ of the respondents considered that the most important consequence was the obtaining of higher prices, while $31 \%$ believed that the delivery of lower quality products was the most important consequence of the corruption phenomenon (Figure 7). Higher operating / maintenance costs over the life cycle had a weight of $6 \%$ and exceeding the delivery terms had a weight of only $2 \%$. 
Preda, I.

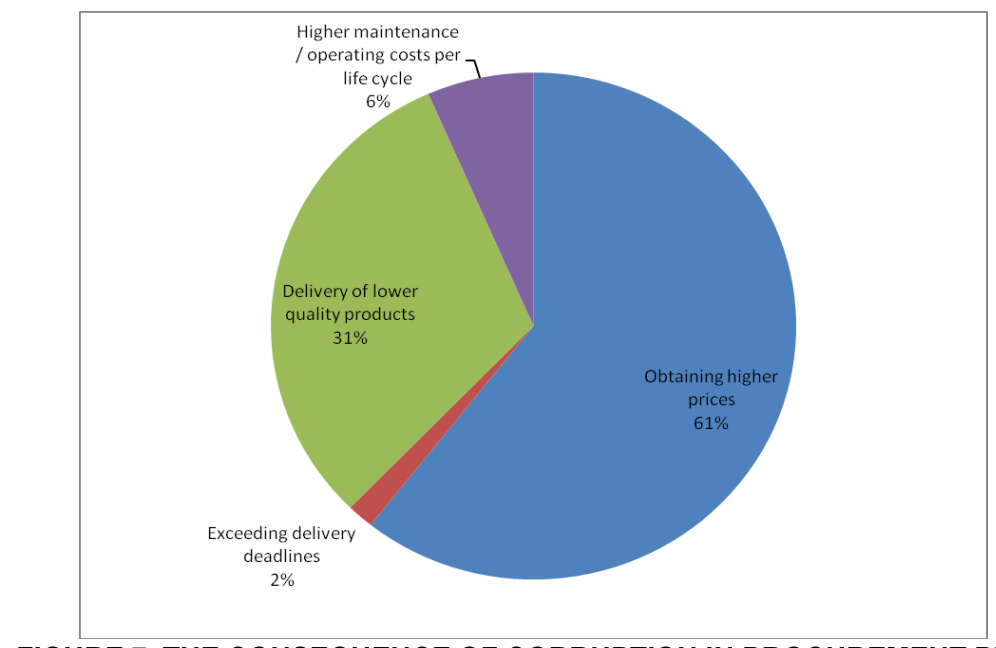

FIGURE 7. THE CONSEQUENCE OF CORRUPTION IN PROCUREMENT PROCEDURES

Source: own processing

The presented results confirm the findings of TIR (2014) which have shown that the financial impact, meaning the increase in contract costs (higher prices), is the most important consequence of corruption in public procurement in Romania.

Analyzing the most likely consequences of corruption acts can lead to the identification of elements / indicators which may constitute red flags for the recognition of procurement procedures whose evaluation and award process has been vitiated. Such alarm signals can be: big differences between estimated values and final values, the number of repairs of a product during the technical warranty period, the number of amendments which increase the value of the contracts or extend the delivery terms, the number of procedures awarded based on a single offer received, high rejection rate of received offers, the repeated award of contracts to the same economic operator, the selection of evaluation criteria, evaluation factors or calculation algorithms which favor a particular offeror and do not reflect the benefits to be gained by the contracting authority, etc.

The size of the bribe demanded by corrupt purchasers (percentage of the contract value) is another much debated topic in Romania. Given that the bribe granted is recovered by increasing the costs of the contracts concluded, the following question was: "What do you think is the percentage that increases contract costs due to corruption?" The results of the answers are shown in Figure 8. 


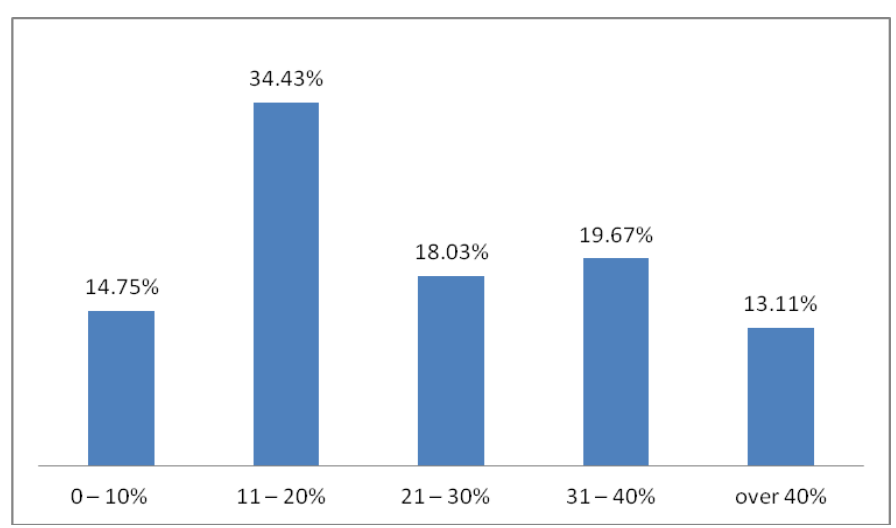

FIGURE 8. THE PERCENTAGE OF INCREASING CONTRACT COSTS DUE TO CORRUPTION

Source: own processing

As can be seen, the structure of the answers is as follows: $14.75 \%$ of the respondents answered between 0 - 10\%, 34.43\% answered 11 - 20\%, 18.03\% answered 21 - 30\%, 19.67 \% answered 31 $40 \%$ and $13.11 \%$ answered over $40 \%$.

If the average percentage reported in the Romanian media is up to $20 \%$, it is surprising that $50.82 \%$ of the respondents answered that the increase of the contract costs is higher than $20 \%$. Also, very surprising is the percentage of $13.11 \%$ cost increase by over $40 \%$.

These results confirm the findings of Evenett \& Hoekman (2005) and TIR (2014), according to which public procurement costs can increase due to corruption by $20-25 \%$, or even by $50 \%$, in some cases.

Also, these results clearly show that the phenomenon of corruption in public procurement is widespread and the most important consequence is the unjustified increase in contract costs.

When a procurement procedure is awarded incorrectly to a tenderer, it is necessary to analyze the causes that lead to the incorrect award.

Therefore, the next question asked to the respondents was: "Who do you think is responsible for the incorrect award of public contracts?"

$62.30 \%$ of the questioned purchasers replied that the evaluation commissions had the greatest guilt and $32.79 \%$ considered that the fault belonged to the leaders of the institutions (especially those appointed on political grounds) and $4.92 \%$ considered that the fault belonged to civil servants in general (Figure 9 ). 
Preda, I.

CORRUPTION: A PROBLEM IN ROMANIAN PUBLIC PROCUREMENT

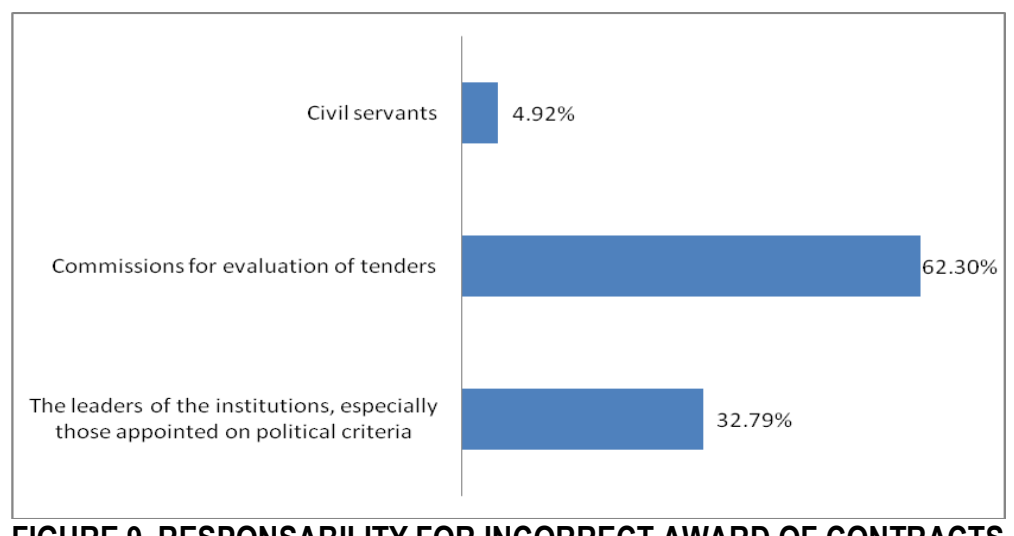

FIGURE 9. RESPONSABILITY FOR INCORRECT AWARD OF CONTRACTS

Source: own processing

Unfortunately, in Romania many heads of public institutions are appointed on political criteria, and they then put pressure on purchasers and evaluation commissions to declare as winner a certain bidder.

The fight against corruption can materialize by taking measures by the regulatory authorities, control institutions or government. The identification of the most effective anti-corruption measure was analyzed by the question: "What is the most effective measure in the fight against corruption in the field of public procurement?"

$61 \%$ of the respondents considered that the most effective anti-corruption measure was to increase the probability of detecting and punishing corruption (Figure 10). 18\% of the respondents considered that the most effective measure was the increase of the transparency of procurement procedures and raising the level of education. The increase of the benefits for honest purchasers had a share of $2 \%$ and the cultural changes accounted for only $1 \%$.

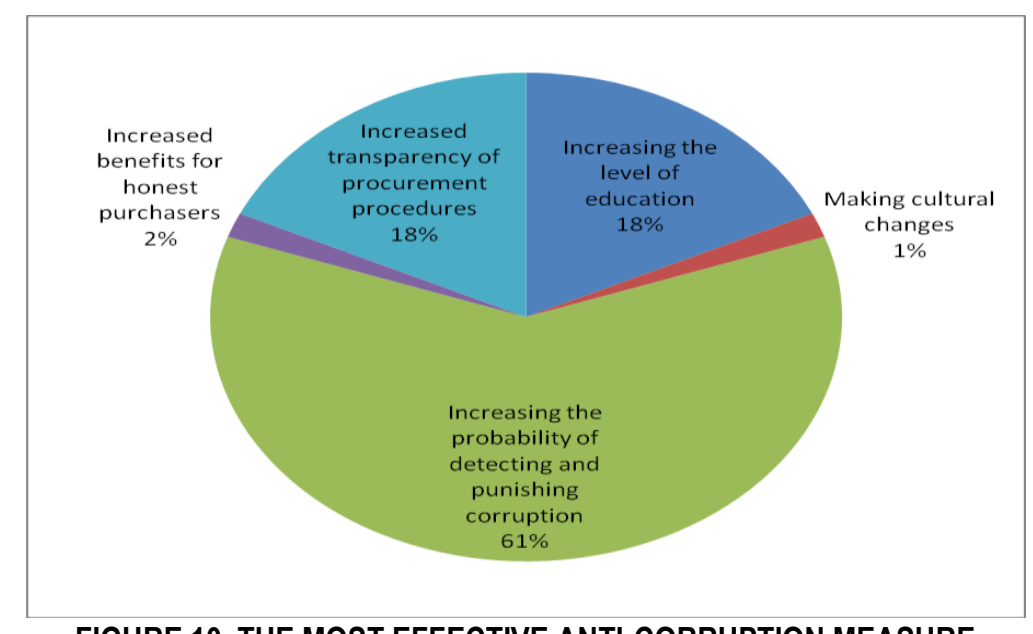

FIGURE 10. THE MOST EFFECTIVE ANTI-CORRUPTION MEASURE

Source: own processing 
In the current socio-economic context of public procurement in Romania, the majority of respondents believe that the most effective anti-corruption measures are the intensification of controls and sanctioning of irregularities, which are coercive measures.

The results confirm the conclusions of the authors Rose-Ackerman (1996), Akbar \& Vujić (2014) and Auti \& Skitmore (2008), who concluded that the most important measures to combat corruption are to increase the probability of detecting and punishing acts of corruption and to increase the level of education.

\section{CONCLUSIONS}

The study contains a survey addressing the main features of corruption in public procurement in Romania.

Most respondents considered that corruption was high, there was no control over corruption, the frequency of corruption was systemic, the restrictive qualification and selection conditions were the most conducive feature of corruption and the negotiation procedure without the publication of a tender notice was the most prone to corruption.

The surveyed purchasers also believed that the most widespread form of corruption was bribery, the most important consequence was higher prices, the costs of contracts increased by more than $20 \%$ due to corruption, the evaluation commissions had the greatest guilt and the most effective anti-corruption measure was to increase the likelihood of detecting and punishing corruption.

Future research on corruption in public procurement should analyze the correlation between corruption and performance indicators of public procurement procedures (number of clarifications requested by potential bidders, number of offers received, number of offers rejected, weight of savings obtained, evaluation time of the bids etc.), comparing these indicators with the level of corruption in the respective country or in other countries. The most difficult challenges are to isolate corruption from other elements that can lead to reduced procurement performance and establish causal relationships between the characteristics / results of the procedures and the level of corruption.

\section{REFERENCES}

Akbar, H., Y. \& Vujić, V. (2014). Explaining corruption: the role of national culture and its implications for international management. Cross Cultural Management: International Journal 21 (2): 191-218, cited in Locatelli, G., Mariani, G., Sainati, T. \& Greco, M. (2016). Corruption in public projects and megaprojects: There is an elephant in the room!'. International Journal of Project Management 35 (2017): 252-268 
Preda, I.

Auti, A. \& Skitmore, M. (2008). Construction Project Management in India. International Journal of Conflict Management, 8 (2): 65-77, cited in Locatelli, G., Mariani, G., Sainati, T. \& Greco, M. (2016). Corruption in public projects and megaprojects: There is an elephant in the room!. International Journal of Project Management 35 (2017): 252-268

Buchner, S., Freytag, A., Gonzalez, L. G. \& Guth, W. (2008). Bribery and public procurement: an experimental study, $1, \quad 2$, Retrieved July $19, \quad 2019$, from https://link.springer.com/content/pdf/10.1007/s11127-008-9315-9.pdf

Cendrowski, H., Martin, J., P. \& Petro, L., W. (2007). The Handbook of Fraud Deterrence. John Wiley \& Sons, Inc.

CJI - The Clean Justice Initiative (2015). Achizițiile publice și crima organizată - 0 analiză la nivel european. Retrieved June 22, 2019, from https:/justitiecurata.ro/achizitille-publice-si-crimaorganizata-o-analiza-la-nivel-european/

Coggburn, J. D. (2003). Exploring differences in the American States' procurement practices', 6 - 23, Retrieved July 21, 2018, from http://ippa.org/jopp/download/vol3/issue-1/Coggburn.pdf

Egger, P. \& Winner, H. (2005). Evidence on corruption as an incentive for foreign direct investment. European Journal of Political Economics, 21 (4): 932-952, cited in Locatelli, G., Mariani, G., Sainati, T. \& Greco, M. (2016). Corruption in public projects and megaprojects: There is an elephant in the room!. International Journal of Project Management, 35 (2017): 252-268

European Commission (2014). Businesses' attitudes towards corruption in the EU. Flash Eurobarometer 374. February 2014. Retrieved June 22, 2019, from http://ec.europa.eu/public_opinion/flash/fl_374_en.pdf

European Commission (2017). Semestrul european - Fișă tematică: Achizițiile publice: 1-13, Retrieved June 20, 2019, from https://ec.europa.eu/info/sites/info/files/file_import/europeansemester_thematic-factsheet_public-procurement_ro.pdf

EC - European Council (2014). Report from the Commission to the Council and the European Parliament, EU Anti-Corruption Report. Brussels 3.2.2014. Retrieved July 18, 2018, from http://ec.europa.eu/internal_market/publicprocurement/docs/implementation/20121011-staffworking-document_en.pdf

Evenett, S. J. \& Hoekman, B. M. (2005). Government procurement: Market access, transparency, and multilateral trade rules. European Journal of Political Economy 21(1): 163-183, cited in Thai, K. V. et al. (2009). International Handbook of Public Procurement. Boca Raton, Florida, Taylor \& Francis Group.

The Global Infrastructure Anti-Corruption Centre - GIACC (2008). Examples of corruption in infrastructure, cited in Locatelli, G., Mariani, G., Sainati, T. and Greco, M. (2016). Corruption in public projects and megaprojects: There is an elephant in the room!. International Journal of Project Management, 35 (2017): 252-268

Gillanders, R. (2014). Corruption and infrastructure at the country and regional level. Journal of Development Studies, 50 (6): 803-819, cited in Locatelli, G., Mariani, G., Sainati, T. \& Greco, M. (2016). Corruption in public projects and megaprojects: There is an elephant in the room!. International Journal of Project Management, 35 (2017): 252-268

Government Emergency Ordinance no. 114/2011 regarding security and defense procurement

Gray, C. \& Kaufmann, D. (1998). Corruption and Development. Finance \& Development, cited in Thai, K. V. et al. (2009). International Handbook of Public Procurement, Boca Raton, Florida, Taylor \& Francis Group 
Kaufmann, D. \& Wei, S.-J. (1999). Does "Grease Money" Speed up the Wheels of Commerce?. NBER Working Paper, cited in Locatelli, G., Mariani, G., Sainati, T. \& Greco, M. (2016). Corruption in public projects and megaprojects: There is an elephant in the room!. International Journal of Project Management, 35 (2017): 252-268

Kaufman, D. (2004). The Costs of Corruption, cited in Thai, K. V. et al. (2009). International Handbook of Public Procurement, Boca Raton, Florida, Taylor \& Francis Group

Kenny, C. (2012). Publishing Construction Contracts to Improve Efficiency and Governance, Proceedings of the ICE - Civil Engineering, 165 (5): 18-22, cited in Locatelli, G., Mariani, G., Sainati, T. \& Greco, M. (2016). Corruption in public projects and megaprojects: There is an elephant in the room!. International Journal of Project Management, 35 (2017): 252-268

Law no.98/2016 regarding public procurement

Law no. 99/2016 regarding sectoral procurement

Law no. 100/2016 regarding works concessions and service concession

Locatelli, G., Mariani, G., Sainati, T. \& Greco, M. (2016). Corruption in public projects and megaprojects: There is an elephant in the room!. International Journal of Project Management, 35 (2017): 252-268

Lefter, A. (2015). Corupție și anticorupție în achizițiile publice. S.P.A.R.L. Dragomir și Asociații. Retrieved June 24, 2019, from http://www.dragomirlaw.ro/articles/Coruptie\%20si\%20anticoruptie\%20in\%20achizitii\%20publice.pdf

Loosemore, M. \& Lim, B., (2015). Inter-organizational unfairness in the construction industry. Construction Management and Economics, 33 (4): 310-326, cited in Locatelli, G., Mariani, G., Sainati, T. and Greco, M. (2016). Corruption in public projects and megaprojects: There is an elephant in the room!. International Journal of Project Management, 35 (2017): 252-268

May, D., Wilson, O.D. \& Skitmore, M. (2001). Bid cutting: an empirical study of practice in south- East Queensland. Engineering, Construction and Architectural Management, 8 (4): 250-256, cited in Locatelli, G., Mariani, G., Sainati, T. \& Greco, M. (2016). Corruption in public projects and megaprojects: There is an elephant in the room!. International Journal of Project Management, 35 (2017): 252-268

Mo, P., H. (2001). Corruption and economic growth. Journal of Comparative Economics, 29 (1): 66-79, cited in Locatelli, G., Mariani, G., Sainati, T. \& Greco, M. (2016). Corruption in public projects and megaprojects: There is an elephant in the room!. International Journal of Project Management, 35 (2017): 252-268

Păceșilă, M. (2004). Aspecte privind combaterea corupției în administrația publică. Revista Administrație și Management Public, 2, pp.114-117

Rahman, I., K., A., Rahman, N., A., A., Azhar, Z., Omar, N., Said, J. (2015). Management Accounting Best Practices Award for Improving Corruption in Public Sector Agencies. Procedia Economics and Finance, 31 (2015): 503-509

Rose-Ackerman, S. (1996). Redesigned the State to Fight Corruption: Transparency, Competition and Privatisation. Public Policy for the Private Sector, No.4, cited in Locatelli, G., Mariani, G., Sainati, T. \& Greco, M. (2016). Corruption in public projects and megaprojects: There is an elephant in the room., International Journal of Project Management, 35 (2017): 252-268

Søreide, T. (2002). Corruption in public procurement: causes, consequences and cures, cited in Locatelli, G., Mariani, G., Sainati, T. \& Greco, M. (2016). Corruption in public projects and megaprojects: There is an elephant in the room!. International Journal of Project Management, 35 (2017): 252-268 
Preda, I.

Shleifer, A. \& Vishny, R., W. (1993). Corruption. Quarterly Journal of Economics, 108 (3): 599-617, SNFC, L.S.N. des C. de fer F., 2015. Le financement de la phase 2., cited in Locatelli, G., Mariani, G., Sainati, T. \& Greco, M. (2016). Corruption in public projects and megaprojects: There is an elephant in the room!. International Journal of Project Management, 35 (2017): 252-268

Tabish S., Z., N. \& Jha K., N. (2011). Analyses and evaluation of irregularities in public procurement in India. Construction Management and Economics, 29 (3): 261-274, cited in Locatelli, G., Mariani, G., Sainati, T. \& Greco, M. (2016). Corruption in public projects and megaprojects: There is an elephant in the room!. International Journal of Project Management, 35 (2017): 252-268

Tabish S., Z., N. \& Jha K., N. (2012). The impact of anti-corruption strategies on corruption free performance in public construction project. Construction Management and Economics, 30 (1): 21-35, cited in Locatelli, G., Mariani, G., Sainati, T. \& Greco, M. (2016). Corruption in public projects and megaprojects: There is an elephant in the room!. International Journal of Project Management, 35 (2017): 252-268

Tanzi, V. \& Davoodi, H. (1998). Corruption, Public Investment, and Growth. The welfare state, public investment, and growth. pp. 41-60, Japan, Springer, cited in Locatelli, G., Mariani, G., Sainati, T. \& Greco, M. (2016). Corruption in public projects and megaprojects: There is an elephant in the room!. International Journal of Project Management, 35 (2017): 252-268

The Anti-Corruption Resource Centre (2015). Glossary, cited in Locatelli, G., Mariani, G., Sainati, T. \& Greco, M. (2016). Corruption in public projects and megaprojects: There is an elephant in the room!. International Journal of Project Management 35 (2017): 252-268

TIR - Transparency International Romania (2014). Riscuri de corupție în achizițiile publice - Excelență

și integritate în achizițiile publice'. Retrieved August 25, 2019, from https://www.transparency.org.ro/proiecte/proiecte_incheiate/2010/proiect_3/Riscuri\%20de\%20corupt ie\%20in\%20achizitii\%20publice.pdf

TI - Transparency International (2015). FAQS on corruption, cited in Locatelli, G., Mariani, G., Sainati, T. \& Greco, M. (2016). Corruption in public projects and megaprojects: There is an elephant in the room!. International Journal of Project Management, 35 (2017): 252-268

Trading Economics (2019). Romania Corruption Index. Retrieved August 25, 2019, from https://tradingeconomics.com/romania/corruption-index

Transparency International (2014). Corruption perceptions index 2014: results. Retrieved August 25, 2019, from https://www.transparency.org/cpi2014/results

Transparency International (2018). Corruption Perceptions Index 2018: Romania', Retrieved August 26, 2019, from https://www.transparency.org/country/ROU

Treisman, D., (2007). What have we learned about causes of corruption from ten years of crossNational Empirical Research?. Annual Review of Political Science, 10 (1): 211-244, cited in Locatelli, G., Mariani, G., Sainati, T. \& Greco, M., (2016). Corruption in public projects and megaprojects: There is an elephant in the room!. International Journal of Project Management, 35 (2017): 252-268

Wedeman, A. (1997). Lootcers and dividend-collectors: corruption and growth in Zaire, South Korea and the Philippine. Journal of Development Areas, 31 (4): 457-478, cited in Locatelli, G., Mariani, G., Sainati, T. \& Greco, M. (2016). Corruption in public projects and megaprojects: There is an elephant in the room!. International Journal of Project Management, 35 (2017): 252-268

Zarkada-Fraser, A. \& Skitmore, M. (2000). Decisions with moral content: collusion. Construction Management and Economics, 18 (1): 101-111, cited in Locatelli, G., Mariani, G., Sainati, T. \& 
Preda, l.

CORRUPTION: A PROBLEM IN ROMANIAN PUBLIC PROCUREMENT

Greco, M. (2016). Corruption in public projects and megaprojects: There is an elephant in the room!. International Journal of Project Management, 35 (2017): 252-268 